\title{
Global Reporting Initiative (GRI) as recognized guidelines for sustainability reporting by Spanish companies on the IBEX 35: Homogeneity in their framework and added value in the relationship with financial entities
}

\author{
Esther Ortiz, Salvador Marín \\ Universidad de Murcia (Spain) \\ esther@um.es,salvlau@um.es
}

Received December 2013

Accepted September 2014

\section{Abstract}

Purpose: The goal of this paper is to show that among the different ways of reporting sustainability information, there is a majority acceptance of voluntary initiatives to establish a homogeneous framework for transparency.

Design/methodology/approach: This paper analyses the non financial reporting disclosed in two years (2010 and 2011) by all the companies listed on the Spanish IBEX 35 in 2010 . The methodology is based on the study of non financial reporting available on the websites of the companies analysed.

Findings: The conclusions highlight that the Global Reporting Initiative sustainability reporting framework has been widely adopted by the firms studied as a global accepted standard in this non financial reporting and as the most important guidelines in this field. From this same descriptive point of view, we conclude that non financial entities which disclose have improved or maintained their banks' balance sheet positions.

Research limitations/implications: This study is based on acceptance as a first step although it needs to be completed with a deeper analysis of the content and its suitability to the stakeholders' information requirements. This descriptive analysis is therefore a first step in continuing research in this field. 
Originality/value: Disclosure of non financial information has been a miscellany of different practices depending on multiple variables. This paper sheds some light on this subject specifically in the comparability of non financial reporting and its relationship with other characteristics of firms.

Keywords: GRI, Sustainability reporting, IBEX 35, Bank funding

Jel Codes: M14, G32

\section{Introduction}

Once companies assume that it is necessary to disclose non financial information, even though the content of these issues is another point to study, and now that the dichotomy between CSR activity and financial performance seems to have been overcome (Crowther \& Caliyurt, 2004), it is time to analyse the acceptance of standards for definition and reporting for this indeterminate activity (Crowther, 2006).

There are today voluntary corporate sustainability initiatives, such as the ten principles of the UN Global Compact, which relies on public accountability, transparency and disclosure to match business operations and strategies around the world with them, or even sustainability reporting frameworks like that provided by the Global Reporting Initiative, which are signed or used around the world as generally accepted initiatives. The GRI guidelines, seem to fulfil the need for standards when reporting, identifying and implementing sustainable practices in the companies since the GRI framework has become de facto the standard in sustainability reporting around the world.

This is the reason for attempting to study the acceptance of these initiatives in a sample of companies that have tradition in sustainability reporting: the Spanish companies on the IBEX 35. So, the aim of this paper is to provide an analysis of the non financial reports of Spanish companies on the IBEX 35 over two years, in order to show that there is a majority acceptance of voluntary initiatives to establish a homogeneous framework for transparency. But this is only a first step, because the next logical one would be to try to check if this reporting really does satisfy the information requirements, and even if it were the right tool to inform stakeholders, this kind of disclosure, it is not enough, and hardly anyone would notice a company's problems from a simple analysis of this disclosure (Ortiz Martínez \& Crowther, 2008).

The paper has four sections. First, we present the relevant literature. This is followed by a section on the research design and the study sample and data collection. Section 3 discusses 
the results and the final section wraps up the paper, addresses limitations and presents potential avenues for future research.

\section{Literature Review}

As explained by Albers and Günther (2011) Corporate Social Reporting it is not a new phenomenon; it has been growing in popularity since the 1970s, although it has even been said that the 1929 stock market crash was one of the consequences of a lack of transparency (White, 2006). What is true is that recently corporate responsibility reporting has become a fundamental imperative for businesses around the world. One good example is that while in 2008 approximately $80 \%$ of the Global Fortune 250 companies provided a social report, which means that only $20 \%$ of the largest companies in terms of sales did not disclose a social report, in 2011 no fewer than 95\% were reporting on their Corporate Responsibility activities. This represents a jump of more than 14 points on the 2008 survey by KPMG (KPMG, 2011).

With each step toward a knowledge-based economy the problems of traditional financial reporting become more evident. So, the gap between accounting methods, measurement tools and financial reporting, and the sources of value creation through knowledge assets is wider than before, as Lev (2004) points out when analysing "information asymmetries" and intangibles valuation.

The reasons for reporting this non financial information voluntarily have been analysed, although there is no clear evidence for them or for the determinants for such reports.

One of the main hypotheses is that companies disclose voluntary information because it leads to direct financial benefits. This is "the win-win proposition" (Levy, Szejnwald Brown \& De Jong, 2010, pp. 90), mainly applicable for shareholders, due to its focus on the direct influence derived from agency or transactions cost theory and deal with monitoring cost and transaction costs.

But this point of view is enlarged when bearing stakeholders in mind because all the stakeholders have an influence on the company (Gray, Kouhy \& Lavers, 1995). Informed stakeholders are the way to reduce information asymmetry through this kind of reporting which reduces the cost of capital for companies (Leuz \& Verrecchia, 2000). This is because the win-win theory is closely related to the concept of "triple bottom line": economic, social and environmental, and so to mechanisms which help to manage the confluence between different stakeholders' interests (Levy et al., 2010). Botosan (2006, pp. 39) concludes that "while no one academic study is perfect, the sum total of the evidence accumulated across many studies 
using alternative measures, samples and research designs lends considerable support to the hypothesis that greater disclosure reduces cost of equity capital". There are studies which prove an association of disclosure and transparency with higher credit ratings. Disclosure means greater security and well governed firms, so companies will decrease the cost of capital. Through voluntary disclosure companies are able to show their efficiency, credibility, and responsiveness (Saxton, Kuo \& Ho, 2012). These firms will have greater possibilities for getting most of their funding through bank loans (Aman \& Nguyen, 2013) (DeBoskey \& Gillett, 2013) (Crabtree \& Maher, 2012).

However the win-win proposition can be interpreted in two ways, because financial performance can easily influence voluntary disclosure, since financially healthy companies can better meet these non financial reporting requirements. This leads one to suppose that these companies are also more likely to disclose voluntarily, and that less indebted companies are more likely to issue such disclosures (Brammer \& Pavelin, 2006).

Another important stream of research highlights that the issue of sustainability disclosure is due to other reasons. For example, Berthelot, Coulmont and Serret (2012) drawing on a sample of Canadian companies listed on the Toronto Stock Exchange, report that investors give positive value to the publication of a sustainability report, so firms investing in the issue of this kind of reports receive a significant premium in financial markets. The same results are also supported by Schadewitz and Niskala (2010) focusing on responsibility reporting according to the Global Reporting Initiative (GRI) in Finland or in Grüning (2011) who finds that disclosure of additional information benefits the market liquidity of German listed companies. Berthelot et al. (2012) conclude that it may be due to an anticipation of lower production costs or/and increased sales arising from a firm's involvement in sustainable development, which must be explored in further research, or due to "sophisticated communication strategies that can generate potential political benefits". Healy, Hutton and Palepu (1999) provide empirical support for the relationship between disclosure policy and positive capital market impact through investors' valuation, bearing in mind that managers try to mitigate any underrating of the company by investors through voluntary disclosure.

Corporate Social Disclosure is also justified by the "legitimacy theory", because it is a tactic that may enable companies to control public pressure. It means using sustainable reporting to send a sign of credibility to the market and using the reports as a communication tool to improve corporate image, because finally the fear of wrong reactions by stakeholders leads firms to report non financial information (Brammer \& Pavelin, 2006). O'Dwyer (2002), however, points out that in Ireland the effect of this disclosure can be the opposite. Disclosure increases social scepticism and raises public demands. 
The disclosure principle which prays that "no news will generally perceived as bad news" leads to the assumption that if a firm has positive information it is going to release it to avoid being penalised by the market, and hence the investors. This is well explained by Albers and Günther (2011, pp. 232) when they write: "For example a company which has used child labour is perhaps better off if it voluntarily issues reports about child labour and its actions to reduce it rather than not reporting it and facing a story in the press which exposes the fact of its having used child labour". Verrecchia (1983) and Dye (1985), however, show that firms can omit some kind of information without being penalised but only in certain circumstances: in a climate of such degree of uncertainty that investors are not able to know if the firm has or not retain information.

Nevertheless, when speaking about Corporate Social Disclosure because of "image causes" it should not be forgotten that non financial reporting is not costless. If the financial benefits are not clear, taking into account the growing costs of increasingly sophisticated and complex non financial reporting, and mainly, the high costs of external auditing and assurance services, these expenses are the ideal candidate to be undercut (Levy et al., 2010, pp 102). Furthermore, when referring to what is called "political sustainability", we have to be alert to the possibility of being distracted by reporting which does not describe the true state of things (Dobbers \& Springett, 2010).

The background examining determinants of voluntary disclosure is extensive and a good portion of the literature has found country specific and industry specific determinants, although there a high number of different variables are studied (see the review included in Table 1 by Albers \& Günther, 2011, pp. 330). Finally, practice says that "bigger companies are better at CR reporting... As a result, any large companies that are not already reporting on CR will soon run the risk of being viewed as less transparent than their peers", that "those industry sectors that have the greatest influence over society and the environment (such as certain sectors of the energy and natural resources industry) show a higher commitment to reporting than other sectors that may be seen as wielding less influence", and finally that "the ownership of a company has a direct impact on their propensity to report CR activity. Publicly listed companies tend to be somewhat more advanced in CR reporting in comparison to other types of ownership structures" (KPMG, 2011).

Some authors studying non financial disclosure (e. g. Bonsón \& Escobar, 2002; Aranguren Gómez \& Ochoa Laburu, 2008; Briano Turrent \& Rodríguez Ariza, 2012) draw on the publicly available information on company websites issued by the Spanish IBEX 35 companies, as we do here finding that there are variables which are significant at the level of information disclosure. 
The Global Reporting Initiative (GRI) is the most important framework for voluntary corporate reporting of sustainable performance worldwide. According to the lastest survey by KPMG published in $2011,80 \%$ of G250 and $69 \%$ of N100 companies adhere to GRI Sustainability Reporting Guidelines.

The GRI has given a common language and assumptions to the corporate social reporting globally used by companies, and it has gained the official recognition by governmental agencies and multilateral organizations such as the UN Global Compact. Although there were several companies and organizations disclosing environmental and social information, their credibility was not support by an independent, neutral, legitimate institution able to issue and steward a reporting framework, and this is the basis of the success of the GRI: "to fill a leadership vacuum in the area of corporate disclosure standards" (White, 2006, pp. 179). GRI has succeeded in coping with the challenge of elevating non financial reporting to a level that is generally accepted as similar to the financial reporting required by governments or other institutions, bearing in mind that it was born as a voluntary initiative. The GRI is one of the first members of the International Reporting Committee, which was established in 2010 to achieve a globally accepted integrated reporting framework. This framework seeks to bring together financial, environmental, social and governance information in a clear, concise, consistent and comparable format.

It seems proven that the GRI has been more successful in increasing its corporate acceptance than in being useful for non governmental organizations or investors and even that is losing importance, at least in the United States, mainly due to a failure to deliver value to stakeholders (Levy et al., 2010).

Some studies use the GRI application levels to try to obtain a measurement of sustainability activities reported by companies (Kaspereit \& Lopatta, 2011); as a case study (Levy et al., 2010) and its strategies are to promote and institutionalize reporting practices (Etzion \& Ferraro, 2010); other studies use the GRI based reports issued by firms as the sustainable information valued by the market (Berthelot et al., 2012; Schadewitz \& Niskala, 2010) or to analyse size, media, country specific factors, or if industry and sustainability performance have a significant influence on whether firms disclose social reports or not (Albers \& Günther, 2011); as the items issued in order to develop a disclosure index for content analysis (Lynch, 2010); or GRI based reports like Corporate Social Responsibility disclosure to discuss if it varies within industries (Cuganesan, Guthrie \& Ward, 2010).

Bearing in mind all this discussion and the literature this paper tries to shed light on the non financial information disclosed according to GRI by IBEX 35 Spanish listed companies, because as White (2006, pp. 185-186) concludes "The "right to know" is part of doing business in the 
twenty-first century. Integration of global capital markets, the capacity of information technology to virtually instantaneously transmit both good and bad news, and sales of products and services worldwide create both a business and an ethical foundation for full disclosure"... "Company stakeholders are a diverse and dispersed group, but all have a right to know what is relevant to their decisions as consumers, investors, workers, and community members. The consequences of deferred, incomplete, or inaccurate information are too evident and too frequent"... "Information is the Best Medicine".

\section{Data and Results}

The sample analysed in this paper includes the reports disclosed by IBEX 35 Spanish listed companies in 2010 in which they issue their non financial information for the previous two years, 2010 and 2011. The Spanish IBEX 35 index is composed of the 35 securities listed on the Stock Exchange Interconnection System of the four Spanish Stock Exchanges, which were most liquid during the control period pursuant to the terms of this regulation. As IBEX 35 Spanish listed companies they are large companies, because in order to quote on a financial market they have to be of a certain size and as the background highlights "the size matters when speaking about this kind of disclosure". It means it is also possible to obtain all this information from the companies' websites and if this is not possible, to use the contact tools offer by the companies to ask for these reports. So, we analyse publicly available information from company websites between February and 30 June 2012.

The industry in which the firm operates has traditionally been an important determinant of the level of corporate responsibility reporting, because there are sectors that have greater influence on society or the environment, (for example the energy or the natural resources industry) than others. The sectors of the Spanish IBEX 35 listed companies in 2010 are included in Table 1, and at first sight there is no influence of the sector on the non financial disclosure.

\begin{tabular}{|l|c|}
\cline { 2 - 2 } \multicolumn{1}{c|}{} & Number of firms \\
\hline Basic Mat./Industry/Constr. & 10 \\
\hline Financial Serv. \& Real Estate & 9 \\
\hline Petrol and Power - & 7 \\
\hline Consumer Services & 3 \\
\hline Technology \& Telecomm. & 3 \\
\hline Consumer Goods & 3 \\
\hline
\end{tabular}

Table 1. Sector of the Spanish IBEX 35 listed companies 
The country of the companies is also important for corporate responsibility reporting. European companies show a more important tradition in reporting on sustainability. In the last international survey conducted by KPMG on corporate responsibility reporting (KPMG, 2011) in the "leading the pack" position there are above all European companies, and within these Spanish companies, because they have been addressing Corporate responsibility and reporting for over a decade.

There are only three companies which do not mention anything about their corporate responsibility reporting. So, 32 out of the 35 firms disclose this information. And there are 3 reports in 2011 not available at the date of this analysis (June 2012). So, finally we have studied 61 reports for the period 2010-2011 (32 in 2010 and 29 in 2011) issued by 32 companies listed on 2010 on the Spanish IBEX 35, although when we analyse the way of reporting it is seen to be miscellaneous as Table 2 shows.

\begin{tabular}{|c|c|c|c|}
\hline & \multicolumn{2}{|c|}{ Number of firms } \\
\hline & & 2010 & 2011 \\
\hline \multicolumn{2}{|c|}{$\begin{array}{l}\text { RESPONSIBILITY (Corporate } \\
\text { Responsibility Report, Corporate Social } \\
\text { Responsibility Report...) }\end{array}$} & 15 & 15 \\
\hline \multicolumn{2}{|c|}{$\begin{array}{l}\text { SUSTAINABILITY (Sustainability Report, } \\
\text { Sustainable Development Report...) }\end{array}$} & 8 & 7 \\
\hline \multicolumn{2}{|c|}{$\begin{array}{l}\text { RESPONSIBILITY and SUSTAINABILITY } \\
\text { (Annual Report of Corporate Responsibility } \\
\text { and Sustainability) }\end{array}$} & 1 & 0 \\
\hline \multirow{2}{*}{$\begin{array}{l}\text { Section of the Annual } \\
\text { Report }\end{array}$} & Responsibility & 3 & 1 \\
\hline & Sustainability & 0 & 1 \\
\hline \multicolumn{2}{|c|}{ INTEGRATED REPORTING } & 3 & 4 \\
\hline \multicolumn{2}{|c|}{ Global Reporting Initiative Indicators } & 2 & 1 \\
\hline
\end{tabular}

Table 2. Type of reports

The great majority of the companies (about two thirds in both years) draw up a separate own report for non financial information. Only a minority uses other options: including this information as a specific section of the annual report; opting for integrated reporting, which means including in the annual report the economic, social, and environmental performance for the purposes of achieving the maximum transparency in its relationship with all its stakeholders; or issuing only the Global Reporting Initiative indicators. The options used for reporting in a separate way cover "responsibility", with different variations: Corporate Responsibility Report, Corporate Social Responsibility Report... or "sustainability": Sustainability Report, Sustainable Development Report... or a mixture of both like "Annual Report on Corporate Responsibility and Sustainability". 
The concept of integrated reporting has emerged in Corporate Responsibility reporting in recent years. It can be used in a simplistic way like including the sustainability information in a separate section of the financial report, although in our classification we have used the concept as something more sophisticated, as has been properly defined by the companies disclosing this non financial reporting, and as the logical future development of this form of non financial reporting, because it implies a full picture of the company's comprehensive business performance.

Something that is recurrent in all the companies analysed is their adhesion to the United Nations Global Compact, with the exception of the two which do not mention anything about their corporate responsibility reporting on their website, and two others, which in spite of reporting sustainable information did not join the initiative during 2010 and 2011 . Thus 31 out of the 35 firms have joined this initiative, launched in July 2000 as a voluntary initiative that relies on public accountability, transparency and disclosure in order to match business operations and strategies around the world with ten universally accepted principles. These principles are derived from: the Universal Declaration of Human Rights, the International Labour Organization's Declaration on Fundamental Principles and Rights at Work; The Rio Declaration on Environment and Development and the United Nations Convention against Corruption. The ten principles are (Table 3), in the areas of Human Rights, Labour, Environment, and Anti Corruption. With more than 8.500 signatories in over 135 countries UN Global Compact is the world's largest voluntary corporate sustainability initiative.

In Spain more than 1000 organisations have signed the UN Global Compact. They have joined since 2004 creating the Spanish Network of the UN Global Compact. If we analyse the year of adherence to UN Global Compact of the studied Spanish listed firms included in table 4, we note that there was a pioneer firm which signed the initiative in 2001, the first year after its launching, and that 13 out 31 , over forty percent $(41,9 \%)$ of these firms, joined UN Global Compact in 2002. It was in 2004, when more than sixty of the companies joined the initiative that they created the Spanish brand, one of the most important around the world as claimed on its website (http://www.pactomundial.org). So, the majority of the IBEX 35 listed Spanish companies have been concerned about and caring for their sustainability and how to report transparently for over a decade. 


\begin{tabular}{|c|c|}
\hline \multicolumn{2}{|r|}{ Human Rights } \\
\hline Principle 1 & $\begin{array}{l}\text { Businesses should support and respect the protection of internationally } \\
\text { proclaimed human rights; and }\end{array}$ \\
\hline Principle 2 & Make sure that they are not complicit in human rights abuses \\
\hline \multicolumn{2}{|r|}{ Labour } \\
\hline Principle 3 & $\begin{array}{l}\text { Businesses should uphold the freedom of association and the effective } \\
\text { recognition of the right to collective bargaining; }\end{array}$ \\
\hline Principle 4 & The elimination of all forms of forced and compulsory labour; \\
\hline Principle 5 & The effective abolition of child labour; and \\
\hline Principle 6 & The elimination of discrimination in respect of employment and occupation \\
\hline \multicolumn{2}{|r|}{ Environment } \\
\hline Principle 7 & $\begin{array}{l}\text { Businesses should support a precautionary approach to environmental } \\
\text { challenges; }\end{array}$ \\
\hline Principle 8 & Undertake initiatives to promote greater environmental responsibility; and \\
\hline Principle 9 & $\begin{array}{l}\text { Encourage the development and diffusion of environmentally friendly } \\
\text { technologies }\end{array}$ \\
\hline \multicolumn{2}{|r|}{ Anti Corruption } \\
\hline Principle 10 & $\begin{array}{l}\text { Businesses should work against corruption in all its forms, including } \\
\text { extortion and bribery. }\end{array}$ \\
\hline
\end{tabular}

Table 3. The UN Global Compact Ten Principles (http://www.unglobalcompact.org)

\begin{tabular}{|c|r|}
\hline $\begin{array}{c}\text { Year of adherence } \\
\text { to UN Global } \\
\text { Compact }\end{array}$ & $\begin{array}{c}\text { Number of } \\
\text { firms }\end{array}$ \\
\hline 2001 & 1 \\
\hline 2002 & 13 \\
\hline 2003 & 1 \\
\hline 2004 & 4 \\
\hline 2005 & 5 \\
\hline 2006 & 0 \\
\hline 2007 & 3 \\
\hline 2008 & 1 \\
\hline 2009 & 2 \\
\hline 2010 & 0 \\
\hline 2011 & 1 \\
\hline
\end{tabular}

Table 4. Year of adherence to UN Global Compact

Since 1999 Global Reporting Initiative (GRI) has provided a comprehensive Sustainability Reporting Framework. As is pointed out on the GRI website, "is widely used around the world. The cornerstone of the Framework is the Sustainability Reporting Guidelines. As a result of the credibility, consistency and comparability it offers, the GRI Framework has become a de facto standard in sustainability reporting". Table 5 includes the number of Spanish firms on the 2010 IBEX 35 which based their responsibility reporting on GRI. Finally of the 35 companies, there are 2 which do not issue any non financial information, or at least, it has not been possible for us to find it, in spite of phone calls, emails and trawling the website, and there is one company that although listed as two brands issued only one global sustainability reports. So, 32 out of 35 companies published this kind of report and, 28 of 32 companies, prepared GRI based 
responsibility reports. In 2011 it is supposed that there will be again 28 companies reporting based on GRI, but there are 3 firms whose responsibility reports are not yet available, so, there are 25 firms with issued GRI based responsibility reporting in 2011. In any case, a large majority of this kind of firms has voluntarily adopted guidelines or principles over the last decade to try to standardize non financial reporting. It is clear that the ten principles of the UN Global Compact are generally accepted and signed by listed firms and that GRI guidelines are a universally recognised set of common standards for disclosure.

\begin{tabular}{|l|l|l|l|}
\cline { 2 - 4 } \multicolumn{1}{c|}{} & \multicolumn{3}{c|}{ Number of firms } \\
\cline { 2 - 4 } \multicolumn{1}{c|}{} & $\mathbf{2 0 1 0}$ & $\mathbf{2 0 1 1}$ \\
\hline Firms with sustainability reports & 32 & 29 \\
\hline GRI based responsibility reporting & 28 & 25 \\
\hline \multirow{2}{*}{ GRI application level } & $\mathbf{A}$ & 1 & 0 \\
\cline { 2 - 4 } & At & 27 & 25 \\
\hline $\begin{array}{l}\text { GRI Organizational } \\
\text { stakeholders }\end{array}$ & Yes & 6 & \\
\cline { 2 - 4 } & No & 22 \\
\hline
\end{tabular}

Table 5. GRI Guidelines in the Spanish companies on the IBEX 35

In 2006 the GRI G2 Guidelines were replaced by the G3 guidelines, which included some modifications to the issues as well as new application level declarations. According to the scope of disclosure, firms can declare applications levels A, B, or C, where A refers to the highest disclosure level. Under G3, the application level can also be verified by GRI or a third party. If a third party is involved, the levels upgrade to $\mathrm{A}+, \mathrm{B}+$, or $\mathrm{C}+$, respectively. (Kaspereit \& Lopatta, 2011, pp. 8). As can be seen in table 5, all the companies listed on the Spanish IBEX 35 try to comply with the highest level of GRI disclosure, and so, all of them declare an application level A+. There is only one company that in 2010 declared level $A$, and the next year, in 2011, it rose to A+ by incorporating the external assurance. There is also a company which does not use GRI in either of the two years, but the 2011 sustainability report states that "we have improved in the corporate social responsibility reporting and want to make the report according to GRI Guidelines in two years".

GRI is a non profit organization, and is funded by different kinds of contributions. One is the funding obtained from Organizational Stakeholders, which are GRI's core supporters and play an important role in GRI governance. There is an Organizational Stakeholder program which includes more than 600 organizations from over 60 countries. However the majority of the company reports analysed in accordance with GRI is about a third of the firms that are GRI organizational stakeholders (see Table 5). Logically they are the firms which adopted GRI guidelines early. 
It is supposed that external assurance enhances the quality of environmental reporting, this is recommended by GRI, and thus gives more credibility to the stakeholders. This is the same as saying "that independent assurance enhances the quality of environmental disclosures just as independent audits have been found to enhance the quality of financial reports" (Moroney, Windsor \& Ting Aw, 2011 pp. 2). Companies seek to demonstrate the quality and reliability of their corporate responsibility data, because companies "without an external assurance program not only run the risk of restatements in the future, but also send the message that corporate responsibility information is not held in as high regard as financial information, which is frequently assured in most businesses" (KPMG, 2011, pp. 28). In the recent crisis of trust, it is also a way to assess the transparency of the information disclosed. The results of the last KPMG survey (KPMG, 2011) show that approximately $45 \%$ of G250 companies currently use assurance as a strategy to verify and assess their corporate responsibility information. In our sample, all the companies with GRI based non financial reports choose to externally verify these reports, with only one exception in 2010, a company that shows a GRI compliance level of $A$, but that in the next year declares an application level $A+$, which means that the GRI information was externally verified (information about GRI application levels is included in Table 5). Moreover, perhaps in an attempt to give its own visibility to this external assurance it is even included as a separate part of the corporate responsibility report, although there are other opinions about these third party assurance, which say that "a large service industry comprised largely of sustainability consultancies and auditing firms has emerged around the revisions of the guidelines, preparations of reports, their verification, stakeholder outreach, and various efforts to standardize and institutionalize the above activities; however, the readership and usage of the reports by NGOs and other civil society organizations, organized labor, and financial analysts are very modest" (Levy et al., 2010, pp. 97).

The GRI application level can be verified by a third party, which adds the + to the level, or also by GRI. GRI offers a service of checking, called "GRI Application Level Check", and as described on the GRI website (http://www.globalreporting.org) this check is not an external assurance, but a complementary assurance, because it indicates the extent to which the GRI Guidelines have been applied and it is a formal confirmation of the company's report status. In our sample, the number of GRI based responsibility reports with application level check has decreased from 21 out of 28 GRI firms in 2010 (75\%) to 16 out of 22 in 2011 (64\%) (data included in Table 6). 


\begin{tabular}{|l|l|c|c|}
\multicolumn{2}{c|}{} & \multicolumn{2}{c|}{ Number of firms } \\
\cline { 3 - 4 } \multicolumn{5}{c|}{} & PWC & $\mathbf{2 0 1 0}$ & $\mathbf{2 0 1 1}$ \\
\cline { 2 - 4 } $\begin{array}{l}\text { External } \\
\text { assurance }\end{array}$ & KPMG & 5 & 6 \\
\cline { 2 - 4 } & Deloitte & 7 & 6 \\
\cline { 2 - 4 } & Ernst and Young & 5 & 5 \\
\cline { 2 - 4 } & Bureau Veritas Certification & 3 & 2 \\
\cline { 2 - 4 } & AENOR & 1 & 1 \\
\cline { 2 - 4 } & SGS ICS Iberica SA & 4 & 3 \\
\hline GRI Application Level Check & 2 & 2 \\
\hline
\end{tabular}

Table 6. GRI Assurance in the Spanish companies on the IBEX 35

Although there seem to be no differences in the quality of the disclosures for assured companies when assured by accountants or consultants according to existing literature (Moroney et al., 2011), in our case the evidence tell us that companies prefer accountants to consultants to assure corporate responsibility reporting (see Table 5). The majority of the analysed firms, about three quarters, use the services of the major accountancy organizations, which is coincident with the results of the last KPMG survey on corporate responsibility reporting (KPMG, 2011 pp. 30), where it is highlighted that "of the assurance providers, the market continues to be dominated by major accountancy organizations that currently hold $71 \%$ of the G250 market and $64 \%$ of the N100", although it also says that "market shares of other provider types appear to have grown slightly at the expense of the technical expert firms who lost market share".

As in the case of the auditors of financial information, the assurance market for corporate responsibility is dominated by the most important accountancy firms and these main assurance providers have generally retained much the same status over time (KPMG, 2011), as is also seen in our sample, and this is included in Table 7. Finally if over the two years we maintain the same firms in the sample and remove those which have not yet issued the information for 2011, we see that there are only small changes in the assurance providers, and these are always within the same group of big accountancy firms, which means that the other certification specialised firms keep their same external assurance firms during the two years. Interestingly one of the Spanish listed companies with the longest trajectory in sustainability reporting, does not use the service of one of the big accountancy and auditing firms for the external assurance of its non financial information. 


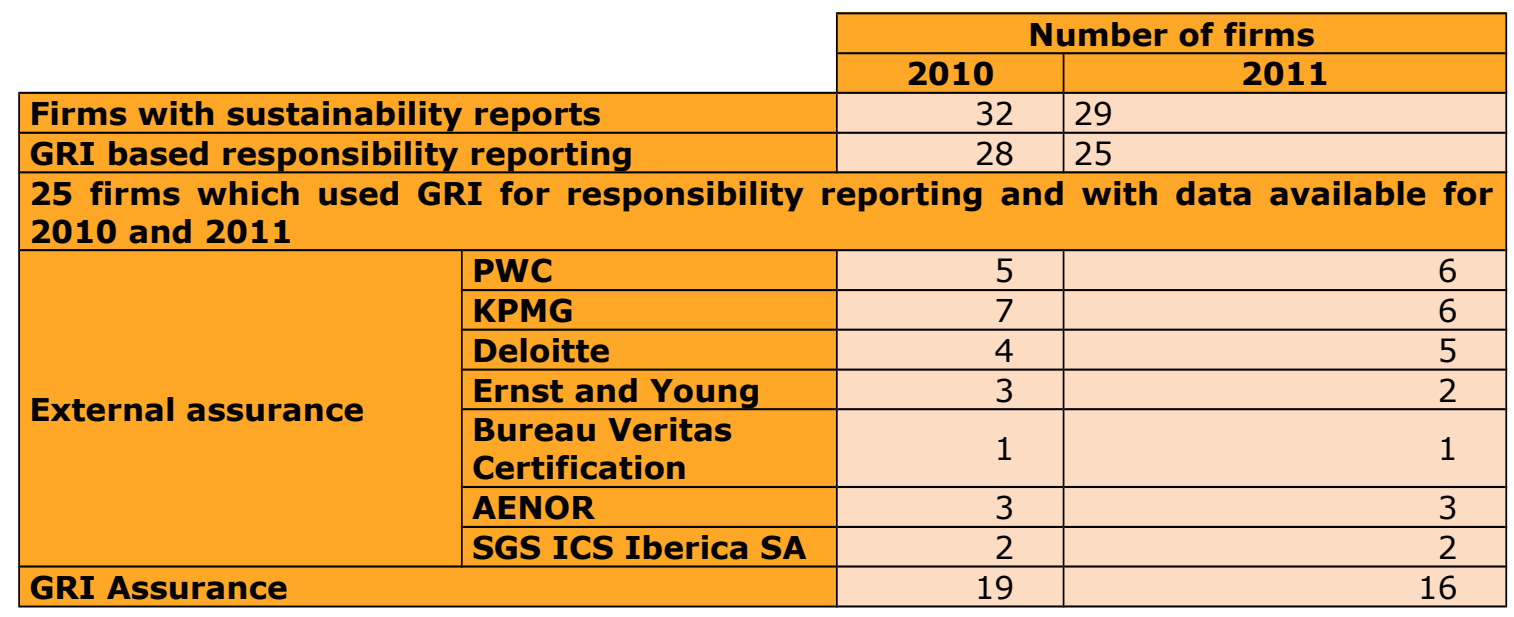

Table 7. GRI Assurance in the Spanish companies on the IBEX 35 with homogeneous data for 2010 and 2011

As a last analysis from this descriptive point of view, we check the situation of bank loans (short and long term) in the non financial analysed firms during these two years (2010 and 2011). This analysis could be really interesting given the special restriction of financial resources from financial entities to non financial ones. We analyse the financial information and find that the majority of the listed non financial entities (more than $70 \%$ of the 26 analysed firms) have increased or maintained their positions in balance sheet with financial entities. Besides this way of obtaining financial resources, other non financial entities negotiated a syndicated loan in this period, which gave them financial peace of mind. Without any doubt, disclosure of non financial information (included in Table 2 ) is a positive added value for the final decision of banks' risk analysts because it decreases the risks (environmental, social, reputational, strategic, and so on, and all of these are of importance within the new methodology of bank risks included in Basel II and III). In spite of not being a statistically proven result, in this first stage, there does seem to be a positive correlation between this kind of information and better bank funding, new or refinanced. This may mean that in periods of financial restriction those companies which elaborate this information will have an additional competitive advantage in obtaining a scarce resource as banks funds are. This is very important because it is a necessary resource in the normal development of companies' business or in meeting growth forecasts. 


\section{Conclusion}

From the analysis of the non financial reporting issued over the last two years by companies of relatively important size, which are listed and operating in different sectors and are included in an important national listing index, such as the Spanish IBEX 35, it is logical to check that there has been a development in the disclosure of non financial information. It is true that the issues are not homogeneous, but it can also be highlighted that over the last decade the habit of reporting on sustainability has been consolidated. The initial trend of trying to separate this non financial information from the financial in order to give it its own visibility and importance may be moving towards and attempt to include all the aspects in the same report: integrated reporting, in order to give a fuller picture of the company's comprehensive business performance.

The route to establishing a homogeneous framework for transparency and disclosure is being undertaken with all these kinds of companies joining voluntary initiatives such as the United Nations Global Compact, and adopting its ten universally accepted principles. In Spain, the trend to disclose sustainability information and the sign of the UN Global Compact, has been adopted by most of these companies.

The Global Reporting Initiative sustainability reporting framework as a globally accepted standard has also been widely adopted by the firms studied as the most serious attempt to standardize these issues. These companies declare maximum applications levels, and in them include third party verification. Although GRI also offers a service of checking, which is not an external assurance, but a complementary assurance, it does not seem to be so widely accepted and popular as the external independent assurance, as this paper confirms. This trend to seek an external assurance for non financial information is also a way for the company to say that there is no difference in the importance given to financial or non financial reporting. Good proof of this is that the assurance market for corporate responsibility is dominated in the sample studied by the most important auditing and accountancy firms. Disclosing this non financial information is also a positive added value for banks' risk analysts, so allowing better access to credit institutions' financing.

This paper is a preliminary one which needs to be complemented with other necessary steps such as studying also the content of corporate social disclosure, obtaining a bigger sample, establishing relationships between the extent and content of non financial disclosure and other variables like profitability, size, sector, among others, or for example identifying whether there is a specific way of disclosing for certain companies such as public companies. 
This future research could be done using the same Global Reporting sustainability reporting framework bearing in mind that in the previous literature on disclosure in Spanish IBEX 35 companies no references have been found that focus on the study of the adoption of a homogeneous framework for transparency.

\section{References}

ALBERS, C.; GÜNTHER, T. (2011). Disclose or not disclose: determinants of social reporting for STOXX Europe 600 firms. Z Plan Unternehmenssteuerung, 21: 323-347. http://dx.doi.org/ 10.1007/s00187-010-0113-4

AMAN, H.; NGUYEN, P. (2013). Does good governance matter to debtholders? Evidence from the credit ratings of Japanese firms. Research in International Business and Finance, 2: 14-34. http://dx.doi.org/10.1016/j.ribaf.2013.02.002

ARANGUREN GÓMEZ, N.; OCHOA LABURU, E. (2008). Divulgación de información sobre empleados y medio ambiente en España y Alemania: Una nota de investigación. Revista de Contabilidad, 11(2): 123-142.

BERTHELOT, S.; COULMONT, M.; SERRET, V. (2012). Do inverstors value sustainability reports?. Corporate Social Responsibility and Environmental Management, 19(6): 355-363. http://dx.doi.org/10.1002/csr.285

BONSÓN, E.; ESCOBAR, T. (2002). A survey on voluntary disclosure on the internet. Empirical evidence from 300 European Union companies. The International Journal of Digital Accounting Research, 2(1): 27-51.

BOTOSAN, C.A. (2006). Disclosure and the cost of capital: what so we know?. Accounting and Business Research, 36(Sup1): 31-40.

BRAMMER, S.; PAVELIN, S. (2006). Voluntary Environmental Disclosures by Large UK Companies. Journal of Business Finance and Accounting, 33(7\&8): 1168-1188. http://dx.doi.org/10.1111/j.1468/5957.2006.00598.x

BRIANO TURRENT, G.C.; RODRÍGUEZ ARIZA, L. (2012). Corporate Information Transparency on the Internet by Listed Companies in Spain (IBEX 35) and Mexico (IPYC). The International Journal of Digital Accounting Research, 12: 1-37. http://dx.doi.org/10.4192/15778517-v12_1

CRABTREE, A.; MAHER, J.J. (2012). Credit ratings, cost of debt, and internal control disclosures: A comparison of SOX 302 and SOX 404. Journal of Applied Business Research, 28(5): 885-902. 
CROWTHER, D. (2006). Standards of Corporate Social Responsibility. Convergence within the European Union. In D. Njavro \& K. Krkaac (Eds.), Business Ethics and Corporate Social Responsibility (pp. 17-34). Zagreb: MATE.

CROWTHER, D.; CALIYURT, K.T. (2004). Corporate Social Responsibility Improves Profitability. In D. Crowther \& K.T. Caliyurt (Eds.), Stakeholders and Social Responsibility (pp. 243-266). Kuala Lumpur: Ansted University Press.

CUGANESAN, S.; GUTHRIE, J.; WARD, L. (2010). Examining CSR Disclosure Strategies within the Australian Food and Beverage Industry. Accounting Forum, 34: 169-183. http://dx.doi.org/10.1016/j.accfor.2010.07.001

DEBOSKEY, D.G.; GILLETT, P.R. (2013). The impact of multi-dimensional corporate transparency on us firms'credits ratings and cost of capital. Review of Quantitative Financial and Accounting, 40: 101-134. http://dx.doi.org/10.1007/s11156-011-0266-8

DOBBERS, P.; SPRINGETT, D. (2010). Corporate Social Responsibility: Discourse, Narratives and Communication. Corporate Social Responsibility and Environmental Management, 17: 63-69. http://dx.doi.org/10.1002/csr.231

DYE, R.A. (1985). Disclosure of Nonproprietary Information. Journal of Accounting Research, 23(1): 123-145. http://dx.doi.org/10.2307/2490910

ETZION, D.; FERRARO, F. (2010). The Role of Analogy in the Institutionalization of Sustainability Reporting. Organization Science, 21(5): 1092-1107.

http://dx.doi.org/10.1287/orsc.1090.0494

GRAY, R.; KOUHY, R.; LAVERS, S. (1995). Corporate social and environmental reporting. A review of the literature and a longitudinal study of UK disclosure. Accounting, Auditing and Accountability Journal, 8(2): 47-77. http://dx.doi.org/10.1108/09513579510146996

GRÜNING, M. (2011). Capital Market Implications of Corporate Disclosure: German Evidence. Business Research, 4(1): 48-72. http://dx.doi.org/10.1007/BF03342726

HEALY, P.M.; HUTTON, A. P.; PALEPU, K.G. (1999). Stock Performance and Intermediation Changes Surrounding Sustained Increases in Disclosure. Contemporary Accounting Research, 16(3): 485-520. http://dx.doi.org/10.1111/j.1911-3846.1999.tb00592.x

KASPEREIT, T.; LOPATTA, K. (2011). The Value Relevance of Corporate Sustainability and Sustainability Reporting in Europe. Electronic copy available at: http://ssrn.com/abstract=1976224

KPMG (2011). KPMG International Survey of Corporate Responsibility Reporting 2011. http://www.kpmg.com/Global/en/IssuesAndInsights/ArticlesPublications/corporate-responsibility/Pages/2011survey.aspx

LEUZ, C.; VERRECCHIA, R.E. (2000). The economic consequences of increased disclosure. Journal of Accounting Research, 38(Suppl.): 91-124. http://dx.doi.org/10.2307/2672910 
LEV, B. (2004). Sharpening the intangibles edge. Harvard Business Review, June: 109-116.

LEVY, D.L.; SZEJNWALD BROWN, H.; DE JONG, M. (2010). The Contested Politics of Corporate Governance. Business and Society, 49(1): 88-115. http://dx.doi.org/10.1177/0007650309345420

LYNCH, B. (2010). An Examination of Environmental Reporting by Australian State Government Departments. Accounting Forum, 34: 32-45. http://dx.doi.org/10.1016/j.accfor.2009.11.001

MORONEY, R.; WINDSOR, C.; TING AW, Y. (2011). Evidence of assurance enhancing the quality of voluntary environmental disclosures: an empirical analysis. Accounting and Finance, 52(3): 903-939. http://dx.doi.org/10.1111/j.1467-629x.2011.00413.x

O'DWYER, B. (2002). Managerial Perceptions of corporate social disclosure. Accounting, Auditing and Accountability Journal, 15(3): 406-436. http://dx.doi.org/10.1108/09513570210435898 ORTIZ MARTÍNEZ, E.; CROWTHER, D. (2008). Is disclosure the right way to comply with stakeholders? The Shell case. Business Ethics: A European Review, 17(1): 13-22. http://dx.doi.org/10.1111/j.1467-8608.2008.00516.x

SAXTON, G.D.; KUO, J.S.; HO, Y.C. (2012). The Determinants of Voluntary Financial Disclosure by Nonprofit Organizations. Nonprofit and Voluntary Sector Quarterly, 41(6): 1051-1071. http://dx.doi.org/10.1177/0899764011427597

SCHADEWITZ, H.; NISKALA, M. (2010). Communication via Responsibility Reporting and its Effect on Firm Value in Finland. Corporate Social Responsibility and Environmental Management, 17; 96-106. http://dx.doi.org/10.1002/csr.234

VERRECCHIA, R.E. (1983). Discretionary Disclosure. Journal of Accounting and Economics, 5; 179-194. http://dx.doi.org/10.1016/0165-4101(83)90011-3

WHITE, A.L. (2006). Why We Need Global Standards for Corporate Disclosure. Law and Contemporary Problems, 69(Summer): 167-186.

Intangible Capital, 2014 (www.intangiblecapital.org) 